\title{
The Spatial Characteristics of Tidal Flood Vulnerability and Adaptation Strategy in Tambak Lorok Kampung Settlement
}

\author{
Akhmad Raditya Maulana Fajrin, Arina Hayati, and Muhammad Faqih \\ Department of Architecture, Institut Teknologi Sepuluh Nopember, Surabaya \\ e-mail: arina_h@arch.its.ac.id
}

\begin{abstract}
The coastal area has an important role in supporting the community development and economics. The problem occurs when the tidal flooding has almost completely engulfed human activities for instance in human settlements. Tidal flooding has a negative impact on physical, social, economic, and environmental conditions, as an example the coastal settlement in Tanjung Mas Village. Tidal flood, in addition, can cause damage on infrastructure and housing areas, also, it has an impact to the live of communities, households, and individuals simultaneously. This research aims to examine on how to determine the vulnerability of community settlements to the danger of tidal flooding and how to build the adaptation efforts among the community to deal with tidal flooding disaster in order to keep the buildings and public facilities in safety. This research uses interview and observation methods, then, by using qualitative descriptive techniques to gain result underlined in the object research. The result shows that Kampong Tambak Lorok can be divided into 3 zones at high, medium and low. This zoning concept is obtained from flood vulnerability assessment related to the high of tidal flood, inundation duration and its impact. The first zone is represented by a high tidal flood with an average threat duration of inundation ranging from 3 to 5 hours. The depth of the tidal flooding can reach around 70-80 $\mathrm{cm}$ from the floor in a house. The second zone is represented by a medium tidal flooding with an average threat duration of inundation ranging from 3 to 4 hours. The depth of the Tidal Flood can reach around $50-60 \mathrm{~cm}$ from the floor. The third zone is a low tidal flooding with an average threat of inundation ranging from 0 to 1 hour. The problem of settlements on monetary and non-monetary factors lies in the economic capacity of the community which is classified as very low, affecting the value of expenditure for settlement needs. This has an impact on the response of the community in dealing with tidal flooding. Adaptation to settlements by elevating the level of floor in the house, changing the position of electricity, elevating the height of the house, making dykes on the front of the house and suctioning the flood by pump.
\end{abstract}

Keywords-Adaptation, Informal Settlement, Tide Flooding.

\section{INTRODUCTION}

$\mathrm{N}^{\circ}$ OWADAYS, many coastal areas in several cities in Indonesia are experiencing severe damage caused by natural phenomena and its geographical characteristic. Problemss that occurs in Indonesia's coastal areas that need to be observed is the phenomenon of the rising of sea levels or better known as Sea Level Rise (SLR) as a result of melting polar ice due to global warming. Climate change has potential to cause catastrophic floods, including an increase in rainfall and an increase in sea level [1]. Even climate change has caused an increase in the surface temperature of the earth so that the ice at the north and south poles of the earth melts. As a result, there was an increase in sea level and affect the occurrence of sea-level rise and affect the occurrence of tidal flooding [2]. It is estimated, that in the next 2100, there will be an increase in the sea level of about 1.4-5.8 m which can cause tidal flooding [3]. Tidal floods occurs in coastal areas often causing stagnant water for days, even weeks, continuously, with high and long periods of water varying depending on the topographical conditions of the region [4].

Areas affected by this disaster are coastal plains located in low coastal areas or coastal wetlands. This inundation also can be triggered by flooding due to rainfall. As result, this flood can occur more severely during the rainy season. According to Sarbidi (2002: 84), Tidal is a pool of water on the coast that occurs during high tides. Tidal floods inundate coastal areas or places lower than the high of tide level (high water level) [5]. The problem of tidal floods that hit areas on the seashore or coast is caused firstly by, lower land surface than the tides level. Land surface conditions that are lower than the water surface conditions that cause difficulty in controlling the flow of water to flow on the surrounding land area, so that the prevention efforts carried out were in vain. Second, increasing sea levels. Various studies of the IPCC (International Panel on Climate Change) have shown that sea levels have risen by 1-2 meters in the last 100 years. According to the IPCC, by 2030, sea levels will increase in between 8-29 $\mathrm{cm}$ from the current sea level [6].

Flooding has a negative effect on physical, social, economic, and environmental conditions. This situation has a negative impact on community assets such as houses and ponds which are important assets in livelihoods [7]. Identification of the impact of disasters in the form of fatalities and economic losses in the short term consisting of the destruction of infrastructure settlements, facilities, and infrastructure as well as other buildings, as well as long-term economic losses in the form of disruption of the economic wheels due to trauma or damage to other natural resources. Vulnerability analysis is emphasized on the physical condition of the region and the impact of the socio-economic conditions of local communities [8]. Disaster vulnerability is part of disaster risk assessment. Disaster risk is the potential loss caused by the disaster in a certain area and period which can be in the form of death, injury, illness, life threatened, loss of security, displacement, damage or loss of property, and disruption of community activities. Disaster risk is the result of the multiplication of vulnerability. The purpose of vulnerability is a natural or artificial phenomenon which has 


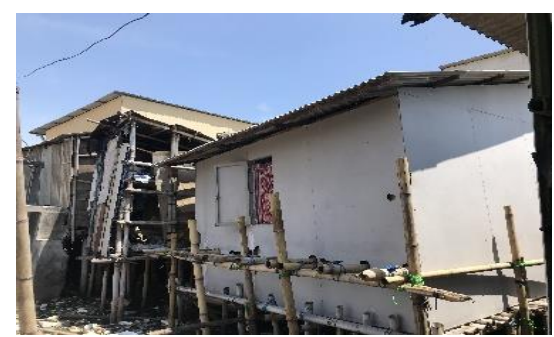

(a)

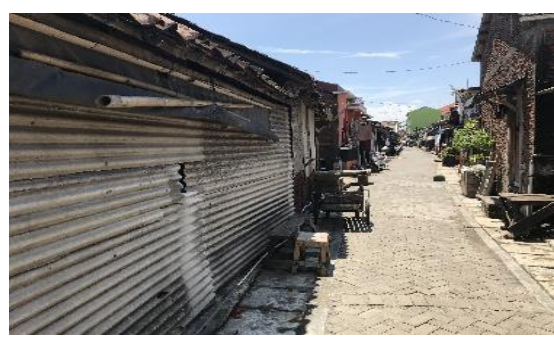

(b)

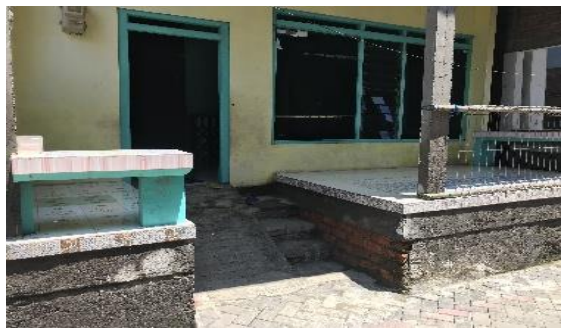

(c)

Figure 1. Housing conditions (a) non-permanent; (b) semi-permanent; and (c) permanent.

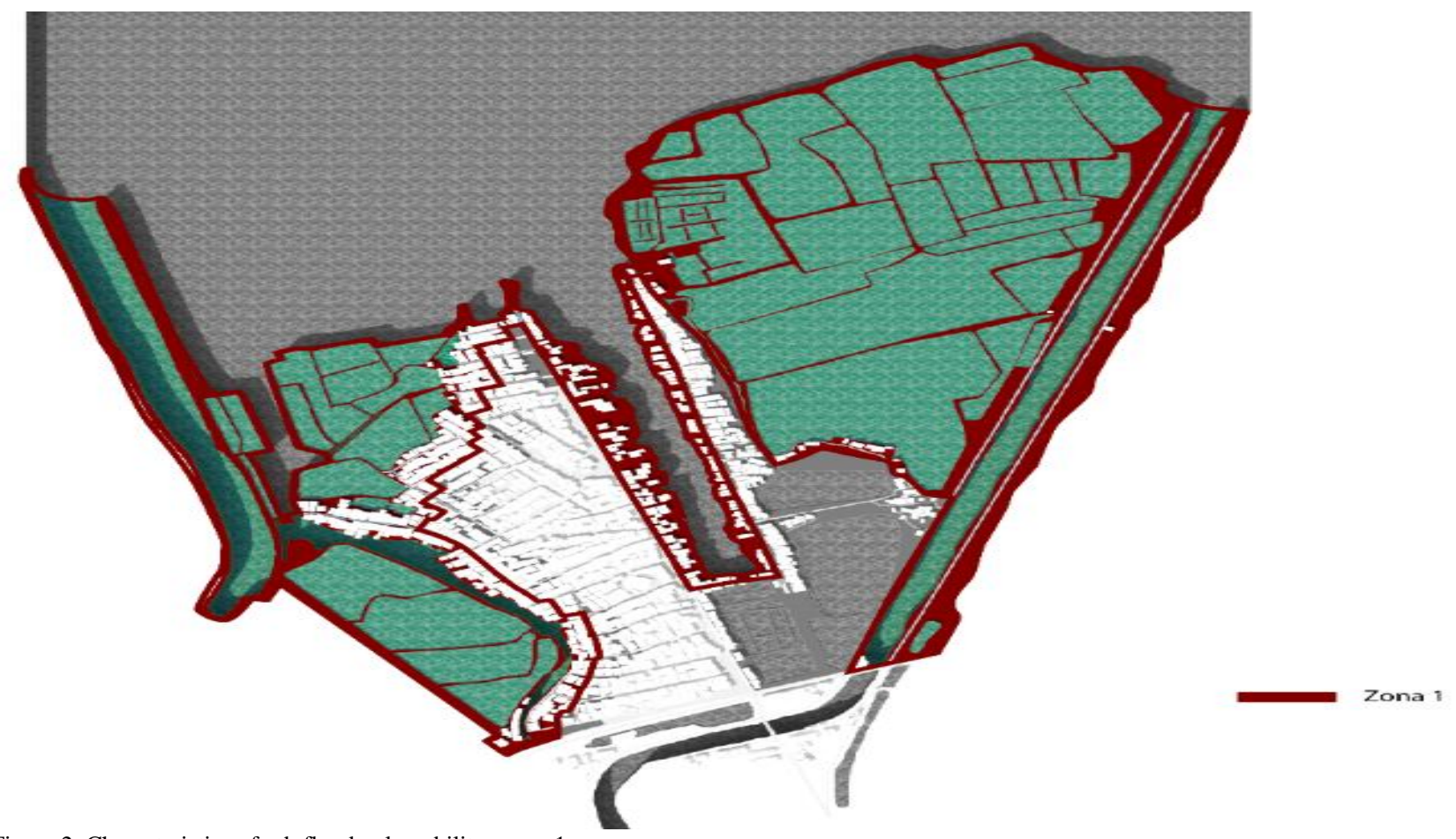

Figure 2. Characteristics of rob flood vulnerability zones 1.

potential to threaten human life, property losses and environmental damage [7].

North Semarang District is one of the places Semarang City which is often suffered by a tidal pool [9]. There is the highest number of buildings inundated compared to other sub-districts in Semarang City [10]. Almost all of the North Semarang District was submerged by tidal flooding [11]. Floods attacked all settlements located in the coastal area of the North Semarang District, but they prefer not to avoid leaving their area, yet, to survive in their own homes. This is because of the limited ability to fulfill a decent life. This indicates the existence of an adaptation effort from the local community.

As a result of this flood, the quality of the environment and people's lives haves drastically declined, besides, there is a tendency for the increasing of the widespread of tides with the increasing of frequency requiring appropriate and optimal countermeasures. The tidal flood in Semarang, in addition, not only causes damage to infrastructure and residential areas, but also simultaneously impacted the lives of people, households, and individuals [12]. Further impacts that will result from tidal inundation are the increase of, changes in coastal ecosystem conditions, the falling coastlines, and the number of damage to buildings near the coast and disruption of population activities in residential, aquaculture and industrial areas which subsections and sub-subsections [13].

\section{THEORITICAL REVIEW}

\section{A. The Comcept oh Housing and Settlements}

Understanding the house, according to Turner (1976), is not a physical result at all, but, rather a process that continou growing and is related to the socio-economic mobility of its inhabitants in a certain period [14]. Besides, Turner believes tha the house is interpreted from several approaches both physical, economic and social. The purpose from the statement is that development of the house has a process in line with the situation of its inhabitants, where usually a household will build a house with their condition at that time. But in the course of time, the house will continue to develop in accordance with the economic level and socio-economic conditions of the occupants. This causes a sense of belonging from each occupant so that the physical, economic and social changes of the occupants are very closely related to the state of the house.

The most important thing in every home is not what the house is but its influence on the lives of residents. Each occupant must be able to determine their own decisions in 
The $6^{\text {th }}$ International Seminar on Science and Technology (ISST) 2020

July $25^{\text {th }}$ 2020, Institut Teknologi Sepuluh Nopember, Surabaya, Indonesia

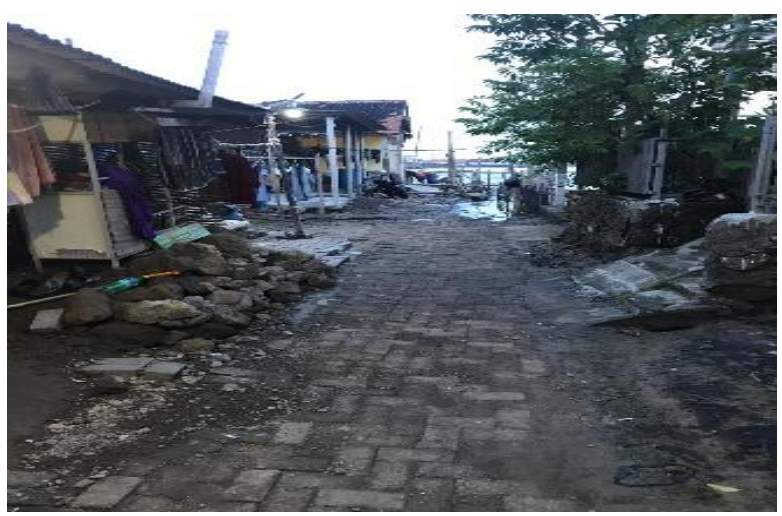

(a)

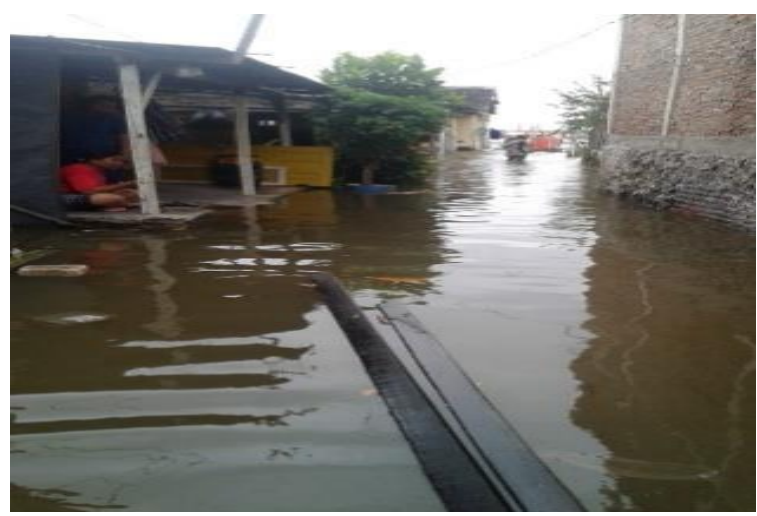

(b)

Figure 3. Housing conditions (a) before of tidal flood and (b) when there is a tidal flood.

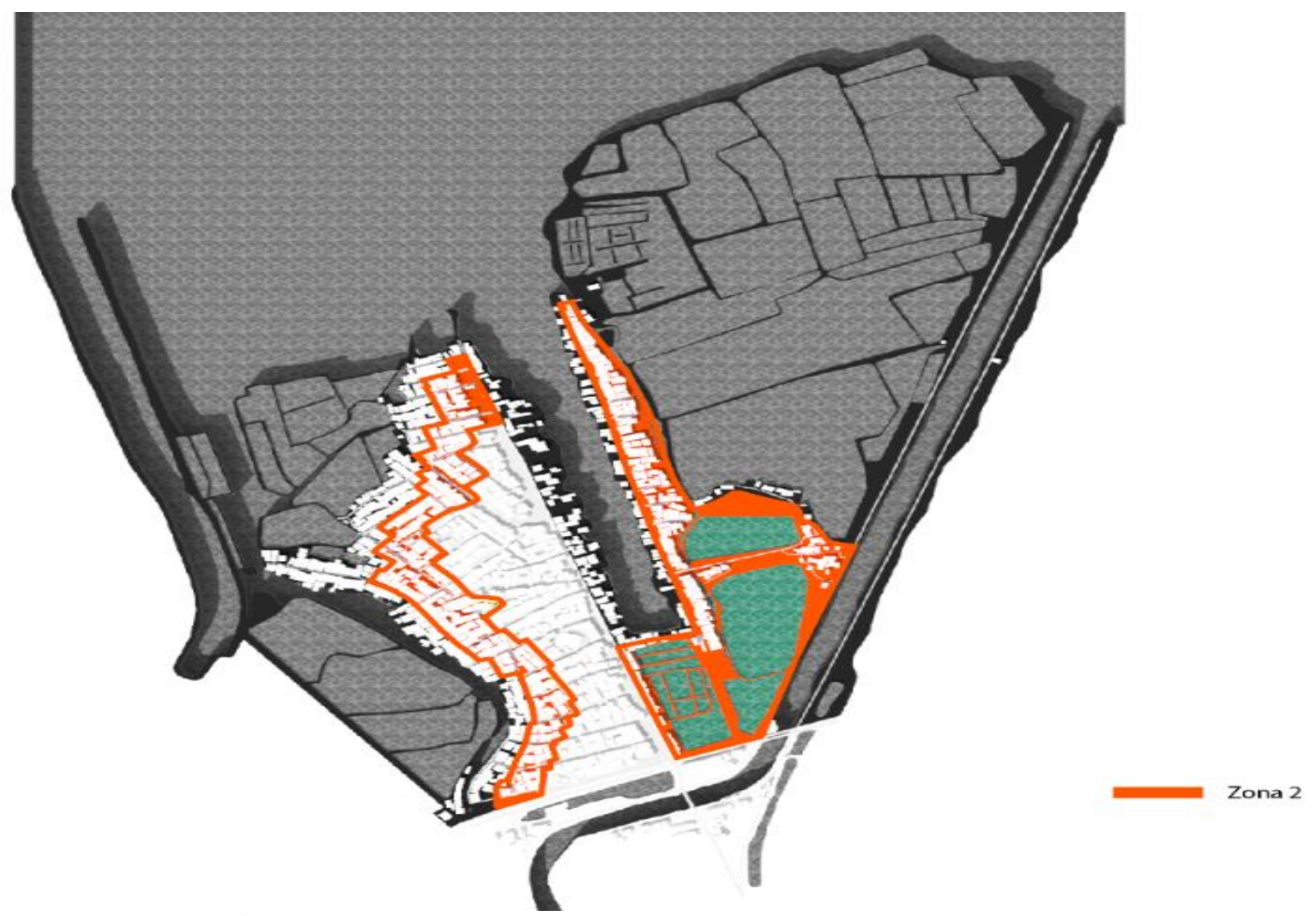

Figure 4. Characteristics of rob flood vulnerability zones 2.

terms of housing because of only those who understand what they need $\mathrm{m}$ ost and the best choice in certain situations. Problems that often occur in the provision of housing are errors in understanding the needs of the community, especially low-income people and the housing supplied by the government. According to Turner, the community must have the freedom to determine housing that suits their needs and standard of living.

\section{B. Settlement Issues: Monetary and Non-Monetary Accounts of Housing Problem}

In a settlement process, Turner (1977) argued that there is a settlement problem in it as well [14]. These settlement problems are discussed in the concept of monetary and nonmonetary accounts of housing problems, as follows: (1) Income: Average total household in multiple of subsistence minimum (S) from below $1,5 \mathrm{~S}$ to above $10 \mathrm{~S}$. A subsistence income is that which leaves about $15 \%$ margin after purchase of minimum food and fuel. (2) Price: rent or amortization, property taxes, utilities, and maintenance paid by household As $\%$ of income from below 5\% to over 30\%. (3) Cost: construction or replacement cost to supplier whatever owneroccupier, developer or landlord. From less than one year's household income to over 5 years income. (4) Fixed Assets: Equity owner by household or key money obtainable. From less than 1 year's income to over 5 years, as above. (5) Social access: dwelling location as a function of proximity to people on whom the household is dependent for social support. From next door to over 1 days return journey. (6) Economic access: dwelling location as a function of proximity to sources of the household's income. From that same street to over 2 hours commute by public transport. (7) Physical standards: space, construction and equipment standards from equipment standards from subserviced to sheltered and serviced to modern standards. (8) Tenure security; the duration of the household's option for continuous residence. From less than 1 month to more than a lifetime. 
The $6^{\text {th }}$ International Seminar on Science and Technology (ISST) 2020

July $25^{\text {th }}$ 2020, Institut Teknologi Sepuluh Nopember, Surabaya, Indonesia

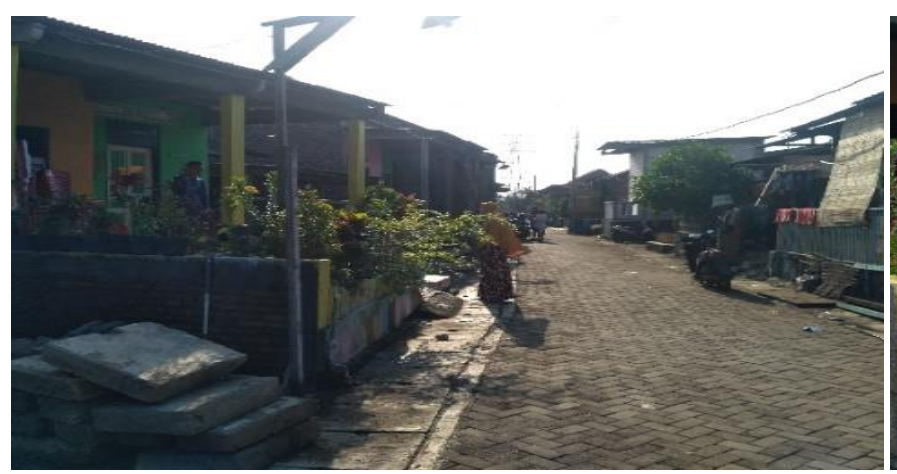

(a)

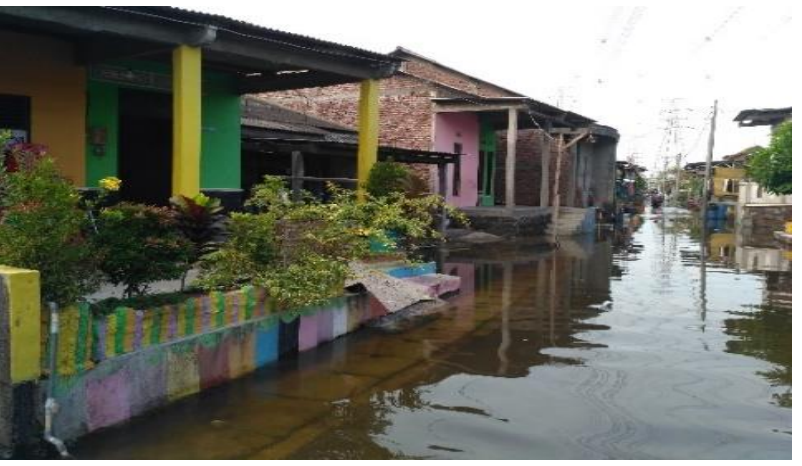

(b)

Figure 5. Housing conditions (a) before of tidal flood and (b) when there is a tidal flood.

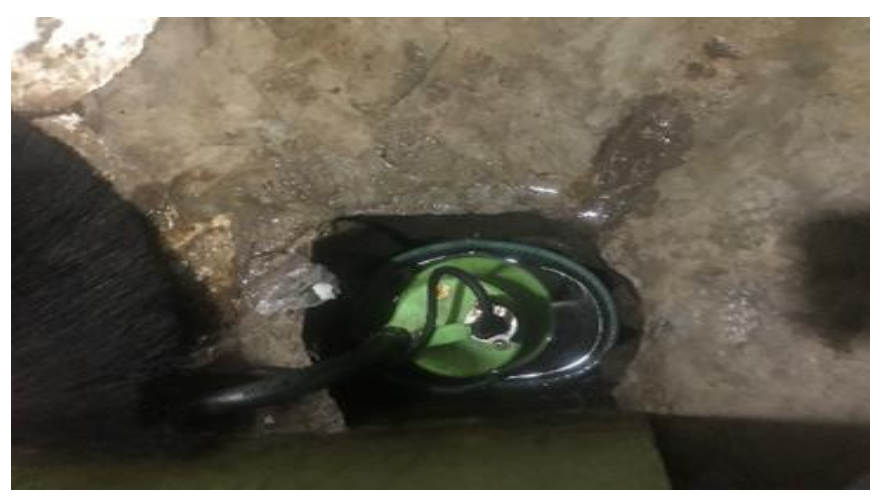

(a)

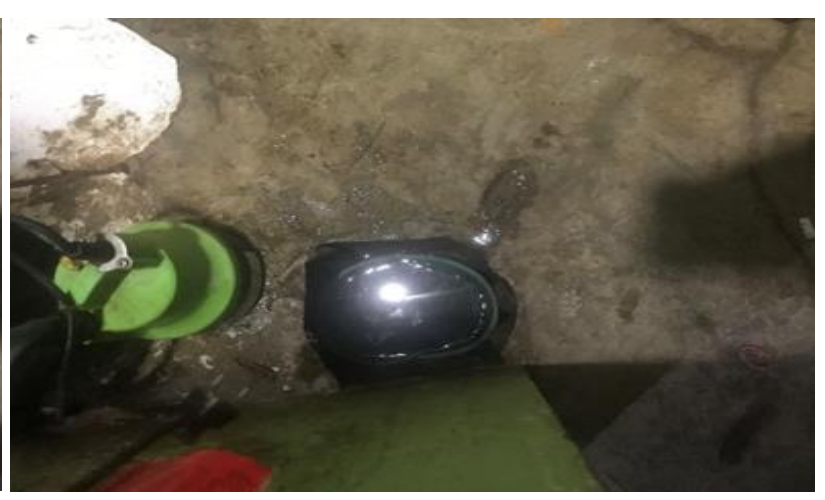

(b)

Figure 6. Housing conditions (a) before of tidal flood and (b) when there is a tidal flood.

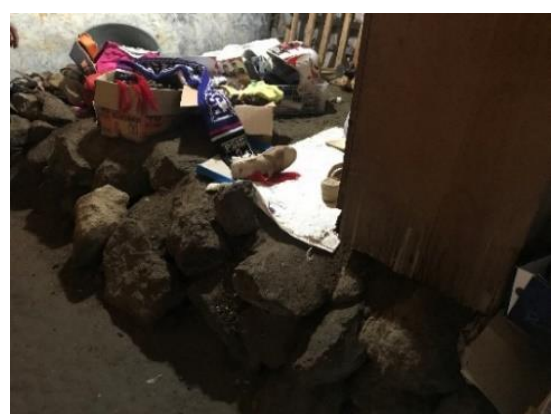

(a)

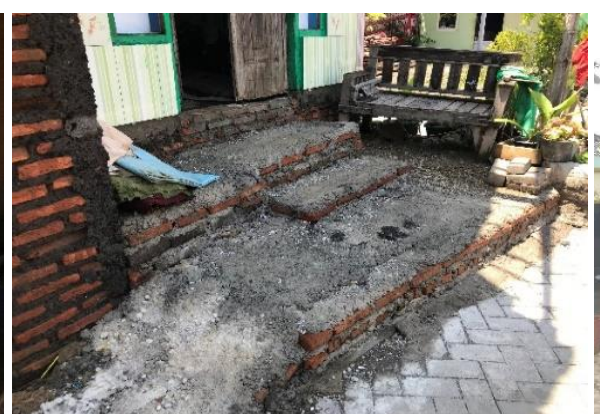

(b)

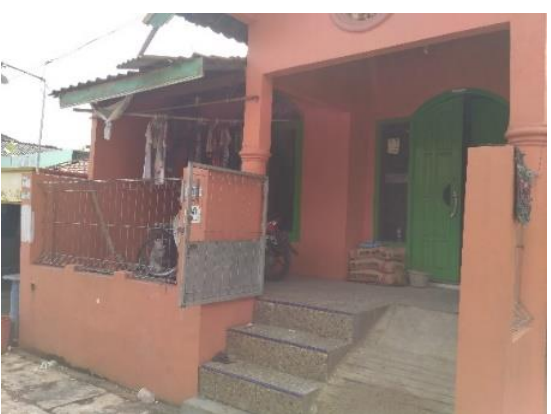

(c)

Figure 7. Condition of the house with adaptation (a) with landfill; (b) with plaster / cement / paving; and (c) with ceramic.

\section{Characteristi cs and Indicators of "Rob" Flood Hazards}

Bakornas PB (2007) useds indicators that to become parameters or benchmarks to measure flood hazards by looking at flood characteristics that occur through inundation area indicators ( $\mathrm{Km} \mathrm{2}$, hectares), depth or height of flood water (meters), flow velocity (meters / second, Km / hour), material that is washed away by flood flow (rocks, chunks, trees, and other hard objects), water level or thickness of silt (meters, centimeters) and length of inundation time (hours, days, months) [15].

\section{METHOD OF ANALYSIS}

The research approach will qualitative descriptive. Qualitative approach is applied to find settlement characteristics based on tidal flood hazard through observation and observation. In addition, it also refers to the form of adaptation carried out by the people of Kampung
Tambak Lorok to buildings and neighborhoods which had the impact of tidal flooding through direct observation and observation. This approach is also to see how the settlement of Tambak Lorok does have settlement problems. The stages in this research process are the stages of data collection that can be done primarily by direct observation, interviews and questionnaires. In this research, the object of research is the people who live in coastal areas and are prone to flooding (Kampung Tambak Lorok). To determine the sample in this study, a sampling technique was used. Sampling technique is a survey technique where only a portion of the population is taken and used to determine the desired traits and characteristics of a population.

\section{RESULT AND DISCUSSION}

\section{A. Overview Kampung Tambak Lorok}

Kampung Tambak Lorok is one of the administrative areas of Tanjung Mas Village which consists of 5 (five) RWs namely, RW 12, RW 13, RW 14, RW 15, and RW 16. It has 
The $6^{\text {th }}$ International Seminar on Science and Technology (ISST) 2020

July $25^{\text {th }}$ 2020, Institut Teknologi Sepuluh Nopember, Surabaya, Indonesia

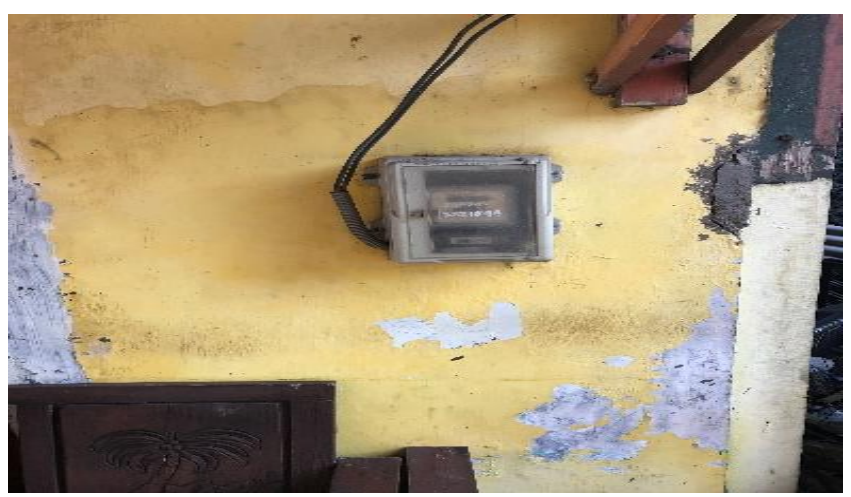

(a)

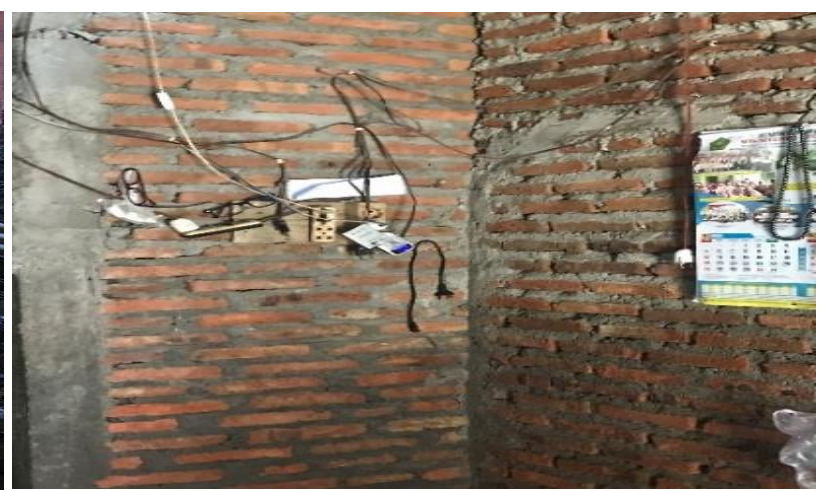

(b)

Figure 8. Condition of the house with adaptation (a) elevate the electric fuse; (b) raise the power jack

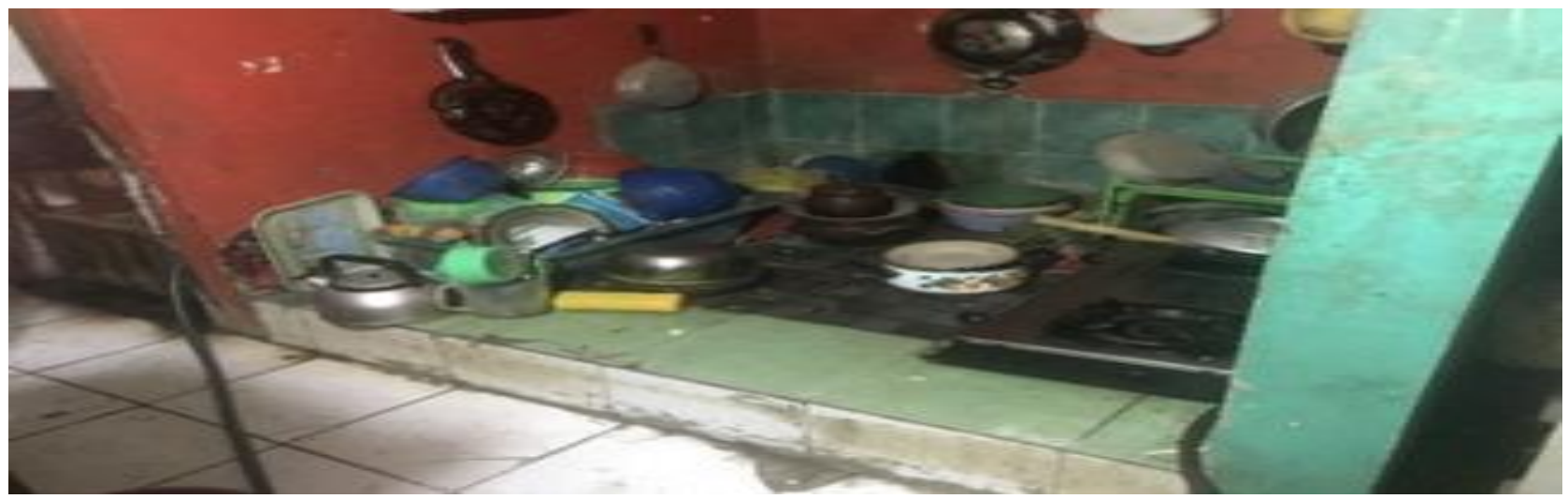

Figure 9. Condition of the house with adaptation to raise the house

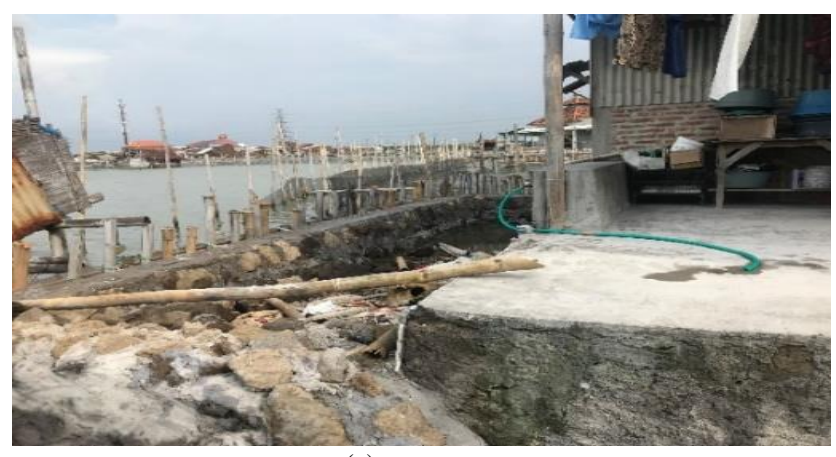

(a)

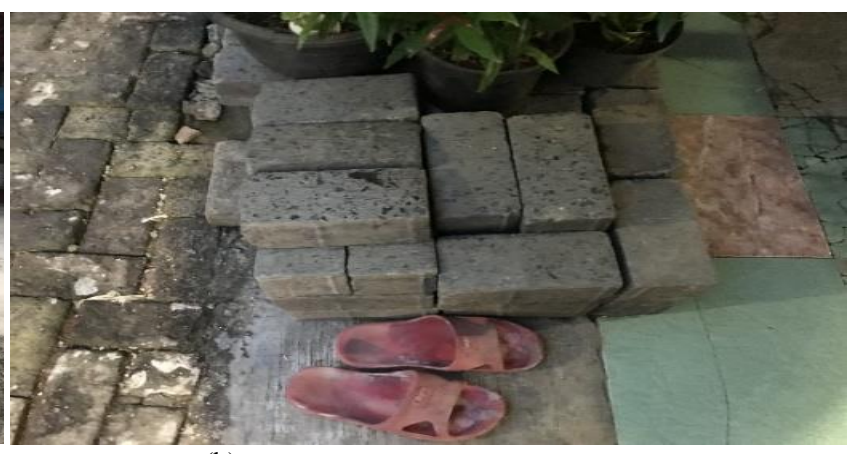

(b)

Figure 10. Condition of the house with adaptation (a) making embankmenst; (b) make a tidal flood barrier

a total area of $46.8 \mathrm{Ha}$ and has an average height of 0.5 meters above sea level. The land use is divided into settlements of 32.4 hectares, the port area on 3.2 hectares, and the use for ponds / ponds on 11.2 hectares. Located on the coast of the Java Sea, with soil in the form of weathering structures, sediments and deep silt. Tambak Lorok soil type is gray, brown and black alluvial soil with low agricultural productivity.

Tambak Lorok area is the mouth of the Kali Banger and the Java Sea, also passed by the East Flood Canal. In 2018, the population in the Tambak Lorok Area was 7085 people, divided into five RWs, namely RW 12 to RW 16 . Of the total population 3506 were male residents and 3579 people were female residents. The number of families in this area is 2054 people. This means that in one KK the average consists of 5 to 6 people.

The majority of the community income level of Tambak Lorok Village is in a very low position, which is at $<\mathrm{Rp}$. $4,260,000$ as much as $41.5 \%$, low classification is in the second place with an income range of $\mathrm{Rp}$. third with an income range of $\mathrm{Rp} 6,521,000-\mathrm{Rp} 8,780,000$ as much as $14 \%$, high classification ranks fourth with an income range of $\operatorname{Rp~} 8,781,000-\operatorname{Rp~} 11,040,000$ by $5.5 \%$ and the last is very high classification with an income range> Rp 11,040 .000 as much as $5 \%$.

\section{B. Characteristics of Housing in Kampung Tambak Lorok}

In settlements, contained in Kampung Tambak Lorok, housing conditions can be categorized into three types namely houses with permanent, semi-permanent and nonpermanent buildings (Figure 1). Based on these types, it can be explained that the settlement of Kampung Tambak Lorok has several characteristics of housing conditions. The condition of this house is influenced by the level of income of the people who are in Tambak Lorok Village. The majority of these non-permanent houses are located in the coastal area in the western village of Tambak Lorok. Whereas the permanent and semi-permanent are scattered evenly 
The $6^{\text {th }}$ International Seminar on Science and Technology (ISST) 2020

July $25^{\text {th }}$ 2020, Institut Teknologi Sepuluh Nopember, Surabaya, Indonesia

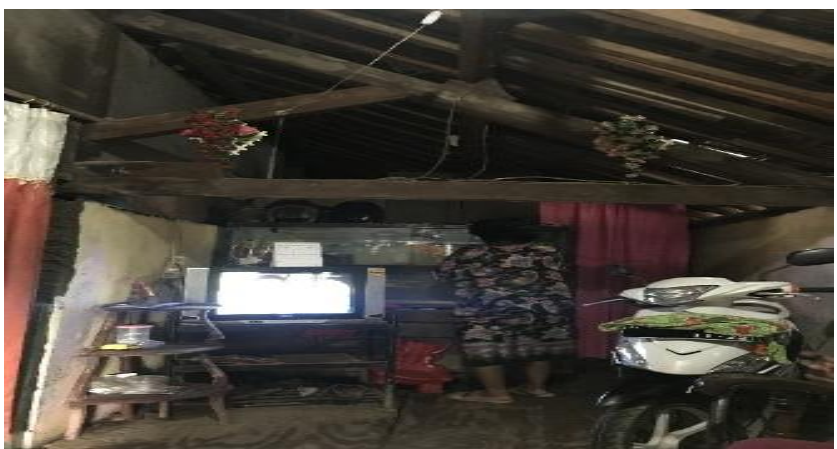

(a)

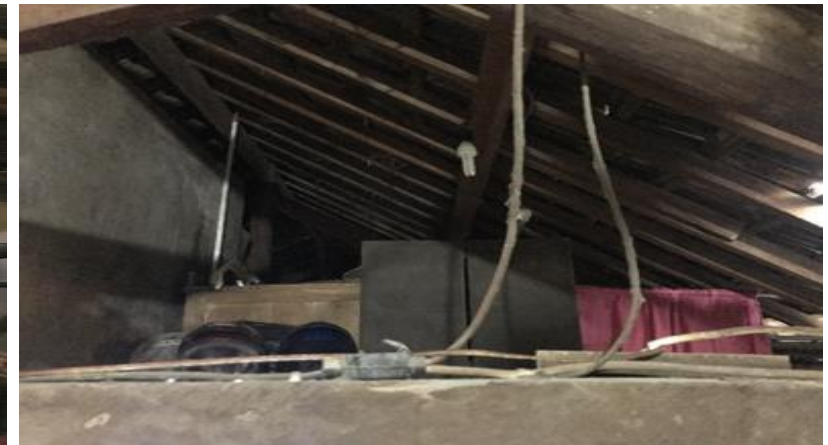

(b)

Figure 11. Condition of the house with adaptation (a) raising the ceiling; (b) turn the ceiling into a place to put goods.

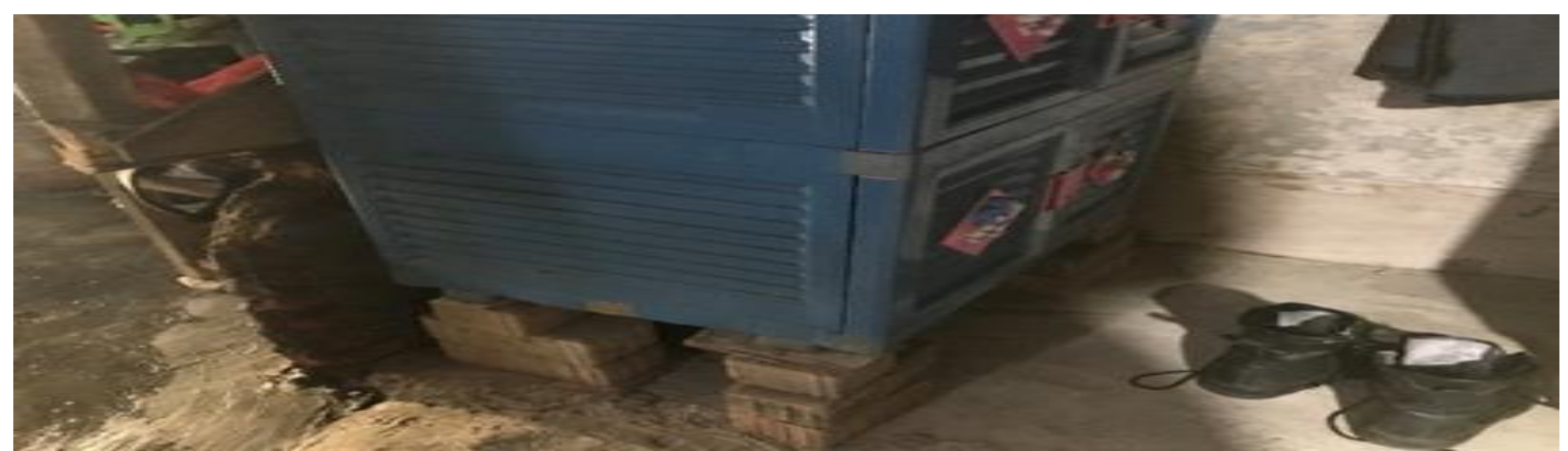

Figure 12. Condition of the house with adaptation with adding cushioning to home furniture and electronic goods

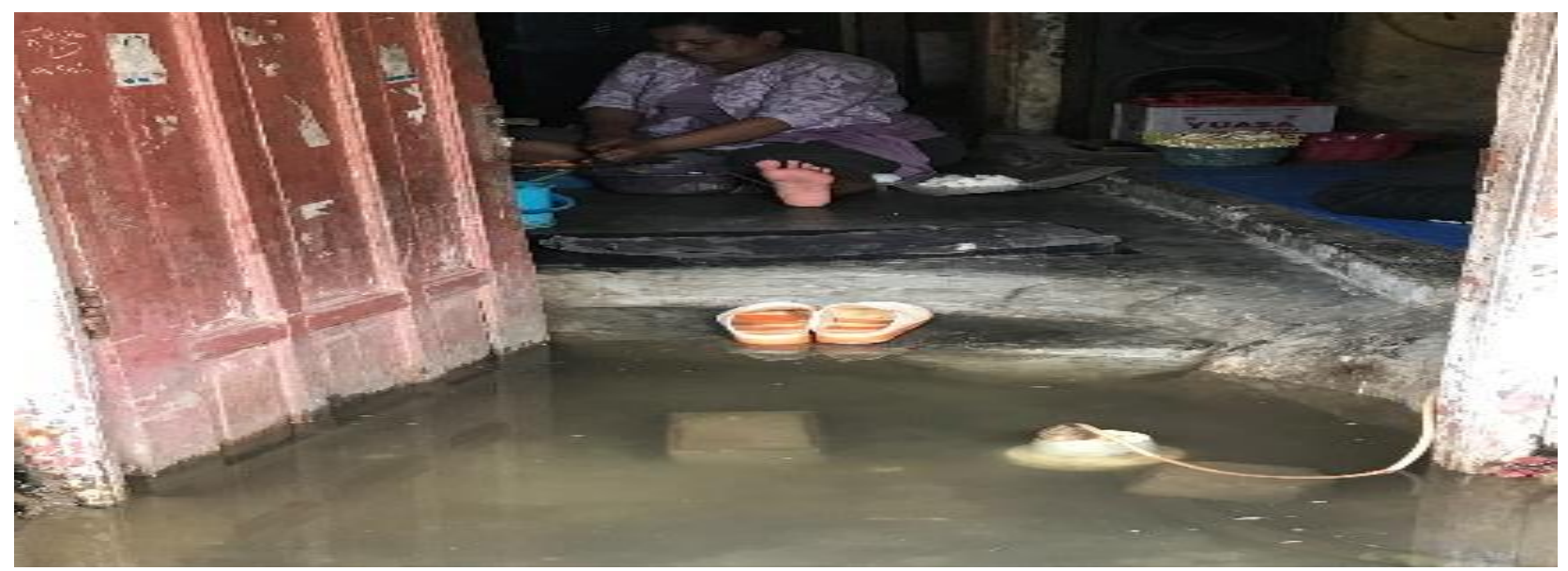

Figure 13. Condition of the house with adaptation by siphoning tidal flood.

throughout Kampung Tambak Lorok. Housing conditions in Kampung Tambak Lorok are classified as slum which is following PUPR Regulation No 2 of 2018 where there are 7 slum indicators. Fishermen settlements, on average, are economically weak people with relatively limited educational background and knowledge of a healthy environment that tends to be lacking.

\section{The Characteristics of Housing in Kampung Tambak Lorok}

Settlement characteristics and tidal flood hazards in Kampung Tambak Lorok can be divided into three zones. The zone was obtained from the results of interviews and mapping conducted by researchers and the community of Kampung Tambak Lorok, so, that three zones were obtained, named zones with high, medium and low levels of tidal flood hazard. The level of the zone is adjusted according to the flood hazard indicator, ie duration, inundation and congenital material, and also based on the impact caused. Following below is an explanation of each zone based on flood hazard indicators [16]. The distribution of settlements in areas vulnerable to tidal flooding was generated. These results are in the form of three tidal flooding scenarios which can be classified as low, medium and high by looking at the height of standing water.

In the Figure 2, the characteristics of zone 1 is settlements directly adjacent to the sea and ponds in Kampung Tambak Lorok which have a high level of vulnerability to the risk of tidal flooding which can be categorized quite high compared to other zones.

The characteristics of the danger of tidal flood zone 1 in Kampung Tambak Lorok for a long frequency of inundation cannot be predicted how long in a matter of hours every day. In Zone 1, the threat of inundation duration based on the results of interviews and observations in the field can be concluded that the average inundation length ranges from 3 to 5 hours (Figure 2). The depth of the Rob Flood, which is 
The $6^{\text {th }}$ International Seminar on Science and Technology (ISST) 2020

July $25^{\text {th }} 2020$, Institut Teknologi Sepuluh Nopember, Surabaya, Indonesia

in zone 1 , is in a settlement directly adjacent to the sea. The depth of the tidal flood itself varies every day depending on the day, month and moon sky. The highest flood level that ever has happened to this coastal area can reach 70-80 cm from the surface of the house, based on interviews and observations.

Based on the Figure 3, it can be seen that the house used as a research sample is located in zone 1 with a distance from the coastline of the north side of 170 meters and the west side of 400 meters and the east side of 20 meters with the condition of the house is higher than the face of the land with the type of high density of settlements, residential type is residential buildings, the height of the road is $10 \mathrm{~cm}$ from the ground and the height of the rob reaches $20 \mathrm{~cm}$.

Characteristics of zone 2 are settlements directly adjacent to zone 1 in Kampung Tambak Lorok which have a high level of vulnerability to the risk of tidal flooding which can be categorized moderately compared to other zones (Figure 4).

The characteristics of the danger of tidal flood zone 2 in Kampung Tambak Lorok for Kampung Tambak Lorok itself for the long frequency of inundation cannot be predicted how long in a matter of hours in each day. In this Zone 2 for the threat of inundation duration Based on interviews and observations in the field it can be concluded that the average inundation length ranges from 3 to 4 hours. The depth of the Rob Flood in zone 2 is in settlements bordering settlements that are at greater risk of tidal floods. The highest flood level that ever happened to this coastal area can reach $50-60 \mathrm{~cm}$ from the surface of the house.

Based on the Figure 5, it can be seen that the house used as a research sample is located in zone 2 with the distance from the coastline of the north side 30 meters and the west side 50 meters and the east side 160 meters with the condition of the house is higher than the face of the land with the type of settlement density is high, residential type is residential buildings, the height of the road is $10 \mathrm{~cm}$ from the ground and the height of the rob reaches $20 \mathrm{~cm}$.

The characteristics of the danger of tidal flood zone 3 in Kampung Tambak Lorok for Kampung Tambak Lorok itself for the long frequency of inundation cannot be predicted how long in a matter of hours in each day. In Zone 3, for the threat of inundation duration Based on interviews and observations in the field it can be concluded that the average inundation length ranges from 0 to 1 hour if there is a very high tidal flood. The depth of the tidal flood in zone 3 which is in bordering settlements that have a greater risk of tidal flooding. The highest level of flooding that occurred in Tambak Lorok Village can reach 30-40 cm.

Based on the Figure 6, it can be seen that the house used as a research sample is located in zone 3 with a distance from the coastline of the north side $720 \mathrm{~m}$ and the west side 120 meters with a house condition lower than the face of the land with a high density type of settlement, residential type is a building where stay, the height of the road is $120 \mathrm{~cm}$ from ground level and the height of rob reaches $10 \mathrm{~cm}$.

\section{Kampung Tambak Lorok Settlement Problems}

As explained in Turner's method, the housing problems can be measured from indicators of monetary factors and non- monetary factors. The measurement is carried out both in the actual condition and its priority, expected, or normal. If there is a discrepancy between the factors above and the occupants' demands and abilities, then housing becomes a problem for the residents.

Based on the analysis related to the monetary factors where there is an income with very low conditions, high prices and costs to pay, it can be said that there are problems in the settlement even though there is a large fixed asset value, but it is still not a priority. Then, it can be said that these factors are experiencing problems because it is burdening the people of Kampung Tambak Lorok. Similar to non-monetary factors where low-income groups in this case achieve the ease in reaching the place of work (economic access).

Theterms of the security of living the people of Kampung Tambak Lorok have very good tenure security as evidenced by the presence of building certificates and the physical standards contained in Kampung Tambak Lorok are the permanent majority with good enough conditions. However, there is a problem, namely the social access of the people who should experience the ease of achieving geography that is not in accordance with the conditions in the field where the community has social access conditions that are far from Kampung Tambak Lorok.

\section{E. Form of Adaptation that the Community Has Towards the Building of the House and Its Environment}

\section{1) Adaptation by Elevating the Floor}

Adaptation carried out by several communities is to raise the floor with a sludge of soil, paving/cement/plastering and ceramics. Elevating the floor serves to prevent water from inundating the house. Costs incurred can reach 5-15 million not including the cost of workmanship. With this elevated floor, the impact on the height in the house increases, but for the height of the house itself remained, thus, the family and guests shall lean when they enter the house This policy was taken as a result of tidal flood inundation that hit Kampung Tambak Lorok. Not a few people who do this form of adaptation are expected to keep the tides of tidal water and can also last for five to ten years (Figure 7).

\section{2) Adaptation by Raising the Electric Plugs and Fuses}

Some people, in order to adapt with the situation, move the electrical plugs and electrical fuses on the wallshigher than it was. This is because the majority of low-income people can only change their homes by raising electrical plugs and electrical fuses on the wall to avoid the shortage of electricity during tidal flooding (Figure 8).

\section{3) Adaptation to Elevate the House}

Increasing the height of walls and parts of the house such as bathrooms, kitchens, etc are also the forms of adaptation carried out by some communities. The aim is to reduce tidal flood inundation into people's homes. The inside of the house such as the kitchen is elevated by providing an additional layer at the base of the cooking area. Whereas in the bedroom and bathroom the height of the floor/base is also done by adding layers so that the rob water cannot enter the bathroom and their bedroom (Figure 9). 
The $6^{\text {th }}$ International Seminar on Science and Technology (ISST) 2020

July $25^{\text {th }} 2020$, Institut Teknologi Sepuluh Nopember, Surabaya, Indonesia

\section{4) Adaptation by Making Dykes and Retaining Tidal Floods}

People make dykes as an adaptation in the area of the house. This has done because some people are only able to change their homes by making embankments around the area of their homes by providing water retardants so that tidal water cannot inundating their homes (Figure 10).

\section{5) Adaptation by Raising the Ceiling}

Dismantling the ceiling to make higher impression is also an adaptation carried out by some people. Moreover, by that dismantled ceiling, people put their stuffs hanging above. This adaptation shows that the house has adapted in the form of increasing the height of the floor in their house so that the height of the house decreases (Figure 11).

\section{6) Adaptation with Adding Cushioning to Home Furniture and Electronic Goods}

Adaptation, which has done by some communities, is to add cushioning to home furniture and electronic goods. This is because middle-income people are only able to add bearings with the aim of being higher so that home furnishings and electronic goods are not submerged in water. The height of the pads is on average as high as $10 \mathrm{~cm}$ (Figure 12).

\section{7) Adaptation by Siphoning Tidal Flood}

Some people, whose houses are submerged by tidal water or water coming out from sanitation, have taken suctioning method, then throw it into the drainage network or drain the water from the house. This is done by the people of Kampung Tambak Lorok as an anticipation and a treatmentrelated to the tidal flood disaster (Figure 13).

In the fixed zone 1 , there are 80 people who have agreed to choose to stay and physically change their buildings with the majority preference by making embankments in the area of the house, elevating the floor with a sloping ground, raising the floor with plastering / cement / paving and changing the location of the electric plugs in sinking by raising it up. In Zone 2, there are 72 communities who have agreed to choose to stay and physically change their buildings, with the majority preference by raising the floor to the ground, changing the electrical fuse higher on the wall and raising the height of the wall. Zone 3 has 72 people who have agreed to choose to stay and physically change their buildings with the majority preference by making embankments in front of the house and changing the electrical fuses in the walls, changing the location of the electrical plugs on the walls by raising them up and raising the floor to the ground. In the semi fix zone 1 , there are 80 people who have agreed to choose to stay and physically change their buildings with the majority choosing to move things to a higher place and provide goods / tools to prevent water from entering the house. Zone 2 has 72 communities who have agreed to choose to stay and physically change their buildings with the majority adding pads to home furnishings and electronics so they are not submerged in water and moving items to higher ground. Zone 3 has 72 communities who have agreed to choose to stay and physically change their buildings with the majority adding pads to home furnishings and electronics so they are not submerged in water and moving items to higher ground.

\section{CONCLUSION}

Kampung Tambak Lorok is a coastal settlement located in the District of North Semarang, Semarang City on which has problem of continous tidal flood to result in tremendous losses in material and non-material. The village still exists today, because it is a fishing village producing main commodity and alsothe largest fisheries area in Semarang. Kampung Tambak Lorok has 3 flood hazard vulnerability zones named high, medium and low. The tidal flood that occurred in the lorok pond village had an impact on settlements, therefore, a monetary factor was foundin the condition of income lower than the price and cost also, nonmonetary factors where the existence of social access did not support many people who do not have a closeness to kinship in one village. The emergence of these problems makes people in Kampung Tambak Lorok adapt to the environment in order to survive. These adaptations are Adaptation by Raising the Floor, Adaptation by raising the electric plugs and fuses, Adaptation to Elevate the House, Adaptation by Making Dykes and Retaining Tidal Floods, Adaptation by Raising the Ceiling, Adaptation with Adding Cushioning to Home Furniture and Electronic Goods and Adaptation by siphoning Tidal Flood. All of these adaptations are influenced by the income of each household, it means that people with high incomes can make a fixed adaptation, while those, with less income, will make a semi-fixed adaptation.

\section{REFERENCES}

[1] Satterthwaite D. 2008. "Climate change and urbanization: Effects and implications for urban governance”. [Editor tidak diketahui]. The United Nations expert group meeting on population distribution, urbanization internal migration, and development. United Nations Secretariat, 21-23Januari. New York.

[2] Diposaptono, Subandono. 2010. "Dampak Perubahan Iklim terhadap Pesisir Pekalongan” dalam laporan National Sharing Workshop: inisiatif Perencanaan dan Assesment: Kota Pekalongan. Jakarta. Indonesia.

[3] Dahuri, R. et al, 1996. "Pengelolaan Sumberdaya Pesisir dan Lautan Secara Terpadu”. Jakarta: PT. Pramadya Paramita.

[4] Nonson, L. 2000. "Hazard Mapping And Risk Assessment": proceeding of the regional workshop on best in disaster mitigation.

[5] Sarbidi, 2002. "Pengaruh Rob pada Pemukiman Pantai (kasus Semarang)”. Prosiding Kerugian pada Bangunan dan Kawasan Akibat Kenaikan Muka AirLaut pada Kota-kota Pantai Di Indonesia, Jakarta.

[6] Pramono SS. 2002. "Analisis Penyelesaian Masalah Banjir di Kota Semarang Dengan Pendekatan Sistem Peringkat Komunitas (SPK)”. Jurnal Desain dan Konstruksi Vol. 1. No.2. Desember 2002:108-115.

[7] National Sharing Workshop 2010 Inisiatif Perencanaan Dan Assessment: Kota Pekalongan; Jakarta, Indonesia.

[8] Diposaptono S. 2005. "Teknologi Mitigasi Tsunami. Materi Kesiapsiagaan dan Tanggap Darurat Bencana Tsunami di Wilayah Pesisir'.

[9] Astuti, Sri. 2009. Reklamasi TipologiBangunan dan Kawasan AkibatPengaruh Kenaikan Muka Air Laut diKota Pantai Semarang. DepartmeneKim Praswil, Bandung.

[10] Miladan, Nur., 2009. "Kerentanan Bencana Banjir Rob Akibat Perubahan Iklim (Kota Semarang)”, Tesis: Universitas Diponegoro.

[11] Ramadhany, A.S., A Anugroho dan P. Subardyo. 2011. "Daerah Rawa Genangan Rob di Wilayah Semarang”. Jurnal Ilmu Kelautan Vol. 1 No. 2. 2012: 174 - 180 .

[12] Marfai MA dan King. 2007. "Coastal Flood Management in Semarang”. Environmental Geology Journal DOI 10.1007/s00254007-1101-3.

[13] Wahyudi, S.I., 2010. "Perbandingan PenangananBanjir Rob di La Briere (Prancis), Rotterdam (Belanda) dan Perspektif di Semarang (Indonesia)": Riptek, Vol.4, No. I1, h 29 - 35. 
IPTEK Journal of Proceedings Series No. (6) (2020), ISSN (2354-6026)

The $6^{\text {th }}$ International Seminar on Science and Technology (ISST) 2020

July $25^{\text {th }} 2020$, Institut Teknologi Sepuluh Nopember, Surabaya, Indonesia

[14] Turner, John F. 1976. "Housing By People-Towards Autonomy In Building Environments". London: Marion Boyars Publishers Ltd.

[15] Bakornas, P. B. (2007). Panduan Pengenalan Karakteristik Bencana dan Upaya Mitigasinya di Indonesia. Jakarta: Badan Koordinasi

Nasional Penanganan Bencana.

[16] Mayasari, M., \& Ritohardoyo, S. (2012). Kualitas Permukiman Di Kecamatan Pasarkliwon Kota Surakarta. Jurnal Bumi Indonesia, 1(3). 